\title{
Heterologous Radioimmunoassay for Llama and Alpaca Luteinizing Hormone with a Monoclonal Antibody, an Equine Standard and a Human Tracer
}

\author{
By $M . A . A b a^{*}$ and M. Forsberg
}

Department of Clinical Chemistry, Faculty of Veterinary Medicine, Swedish University of Agricultural Sciences, Uppsala, Sweden.

\begin{abstract}
Aba, M.A. and M. Forsberg: Heterologous radioimmunoassay for llama and alpaca luteinizing hormone with a monoclonal antibody, an equine standard and a human tracer. Acta vet. scand. 1995, 36, 367-375. - A radioimmunoassay for llama and alpaca LH was developed using a human $\mathrm{I}^{125} \mathrm{LH}$ tracer from a commercial kit, equine LH diluted in human LH free serum as standard, and a monoclonal antibody (518B7) specific for LH but with low species specificity. A 60 -min delay in the addition of the tracer and overnight incubation gave a sensitivity of $0.8 \mu \mathrm{g} \mathrm{\textrm {L } ^ { - 1 }}$. The intra-assay coefficient of variation was $37 \%$ at $1 \mu \mathrm{g} \mathrm{L}^{-1}$, declined to $15 \%$ at $4 \mu \mathrm{g} \mathrm{L}^{-1}$ and was below $6 \%$ for concentrations up to $32 \mu \mathrm{g} \mathrm{L}^{-1}$. The inter-assay coefficients of variation for 3 control samples were $20 \%\left(2.8 \mu \mathrm{g} \mathrm{L}^{-1}\right), 16 \%\left(7.1 \mu \mathrm{g} \mathrm{L}^{-1}\right)$ and $9.8 \%\left(19 \mu \mathrm{g} \mathrm{L}^{-1}\right)$. In an attempt to increase sensitivity, all tubes were preincubated for $4 \mathrm{~h}$ at room temperature before adding the tracer, and the sample volume was increased from $50 \mu \mathrm{L}$ to $100 \mu \mathrm{L}$ (in the standard curve the increased volume was compensated for by human $\mathrm{LH}$ free serum). With this protocol, the assay sensitivity was $0.5 \mu \mathrm{g} \mathrm{L}^{-1}$. The assay was validated clinically and demonstrated increased concentrations of $\mathrm{LH}$ after mating in llamas and alpacas. Furthermore, the assay was used to monitor LH responses to a single dose of GnRH in llamas (adult males and females at different ages).
\end{abstract}

LH; RIA; American camelids.

\section{Introduction}

The 2 domesticated South American camelids, the llama (Lama glama) and the alpaca (Lama pacos), are induced ovulators requiring copulation to trigger the luteinizing hormone (LH) pre-ovulatory peak (Novoa 1970 ). Currently, only a few reports on the endocrin-

* Permanent address: Department of Physiopathology, Faculty of Veterinary Sciences, U.N.C.P.B.A., Campus Universitario, Paraje Arroyo Seco, Tandil, Buenos Aires, Argentina. ological events related to this phenomenon are available. To be able to better understand the physiology of the ovulatory process and develop new techniques for improving the reproductive performance of llamas and alpacas, the determination of $\mathrm{LH}$ in the peripheral circulation is essential.

An assay for llama and alpaca LH (lamLH) that utilizes an antibody to lamLH, iodinated lamLH as a tracer and lamLH as standard would be the ideal assay system, since real values of hormone concentrations could be obtained. To our knowledge, no purified 
lamLH or anti-lamLH antibody is available, making such an assay system difficult to develop. However, the problem could be partly overcome by using LH antisera, which show a high degree of cross-reactivity between species. Although it would be preferable to use standard and tracer from the species being tested, if cross-reactivity is sufficient, $\mathrm{LH}$ from another species can be used. It should be emphasized, however, that this kind of assay cannot be used to quantitate absolute concentrations of LH in the llama or alpaca if the LH standard originates from another species. Such a heterologous assay system for lamLH was recently reported by Bravo et al. (1990). Unfortunately, the ease and widespread availability of hormone assays and, in particular, assay kits have led to the uncritical use of assays without proper validation. This, in turn, has resulted in a lack of information concerning the limitations that should be attached to the interpretation of the test results. In developing a new assay method, one of the primary concerns should be verification of the method's validity. Does the assay measure what it is supposed to measure? This question is highly relevant in the development of assays using cross-reacting antibodies and hormone preparations from species other than the one being tested. Many laboratory techniques (parallelism, interference studies, etc.) can be used to reveal assay-related errors. But are they sufficient tests of assay validity? Or should the usefulness of the test system ultimately be judged based on its diagnostic ability and the clinical information that it provides?

The aim of this study was to develop a radioimmunoassay (RIA) for lamLH while taking the above-mentioned concerns into consideration. Our test system uses cross-reacting anti-LH antibodies and $\mathrm{LH}$ from other species as tracer and standard.

\section{Materials and methods}

Reagents

All common reagents were of pure analytical grade (if not specified otherwise, they were purchased from SIGMA, St. Louis, MO, U.S.A.).

\section{Assay buffer}

Assay buffer was prepared as follows:

A. $9 \mathrm{~g} \mathrm{NaCl}$ in $1000 \mathrm{~mL}$ distilled water.

B. $0.5 \mathrm{~g}$ merthiolate in $50 \mathrm{~mL}$ distilled water.

C. $6.95 \mathrm{~g} \mathrm{NaH}_{2} \mathrm{PO}_{4}$ in $500 \mathrm{~mL}$ distilled water.

D. $3.72 \mathrm{~g}$ EDTA and $1 \mathrm{~mL}$ of $1 \%$ merthiolate in $100 \mathrm{~mL}$ of $0.9 \% \mathrm{NaCL}$.

E. $2 \mathrm{~g} \mathrm{BSA}$ and $0.2 \mathrm{~mL}$ of $1 \%$ merthiolate in $10 \mathrm{~mL}$ of $0.9 \% \mathrm{NaCL}$.

The assay buffer contained $380 \mathrm{~mL}$ of $\mathrm{A}, 10$ $\mathrm{mL}$ of $\mathrm{B}, 500 \mathrm{~mL}$ of $\mathrm{C}, 100 \mathrm{~mL}$ of $\mathrm{D}$ and $10 \mathrm{~mL}$ of $\mathrm{E}$. The buffer was adjusted to $\mathrm{PH} 7.4$ - 7.5 with sodium hydroxide and stored at $4^{\circ} \mathrm{C}$.

\section{Tracer}

The iodinated $\mathrm{LH}$ (hLH double antibody RIA kit [KLHD], Diagnostic Products Corporation, Los Angeles, CA, U.S.A.), with a radioactivity of less than $100 \mathrm{kBq}$ per 100 tube kit, was used as labeled hormone. The freeze-dried tracer was dissolved in $10 \mathrm{~mL}$ distilled water and further diluted in assay buffer to obtain about $25000 \mathrm{CPM}$ per $100 \mu \mathrm{L}$.

\section{Monoclonal antibodies}

Two monoclonal antibodies, MAB 518B7 (generously donated by Dr. Jane F. Roser) and MCA 146 (Serotec, Oxford, U.K.), both generated against bLH, were tested. These antibodies have shown the ability to recognize LH from several mammals (MAB 518B7: Matteri et al., 1987, Forsberg et al., 1993; MCA 146: Kofler et al., 1981). The original solution of MAB 518B7 $\left(1 \mathrm{mg} \mathrm{L}^{-1}\right)$ was stored at $-20^{\circ} \mathrm{C}$ and further diluted with assay buffer before use to give an initial concentration of $10 ; 6.6$ 
and $3.3 \mu \mathrm{g} \mathrm{L}^{-1}$. The MCA 146 antibody, in an original solution containing $4 \mathrm{mg} \mathrm{L}^{-1}$, was diluted with assay buffer to give an initial concentration of $110 \mu \mathrm{g} \mathrm{L} \mathrm{L}^{-1}$.

\section{Standards}

Stock solution containing $1 \mu \mathrm{g} \mu \mathrm{L}^{-1}$ of eLH, lot $\mathrm{n}^{\circ}$ E263B, (generously donated by Dr. H. Papkoff) was prepared in assay buffer and stored in $100 \mu \mathrm{l}$ aliquots at $-20^{\circ} \mathrm{C}$. The stock solution was diluted in assay buffer before use to obtain a standard curve ranging from 0.50 to 32 $\mu \mathrm{g} \mathrm{L}^{-1}$. Human $\mathrm{LH}$ free serum was obtained from Diagnostic Products Corporation, Los Angeles, CA, U.S.A. All values reported in the study are expressed as $\mu \mathrm{g} \mathrm{L}^{-1}$ of the equine LH standard.

\section{Ligand separation}

Separation of free hormone from antibodybound hormone was achieved by centrifugation at $3000 \mathrm{rpm}$ for $20 \mathrm{~min}$ after adding $1 \mathrm{ml}$ of a second antibody coupled to Micro Sepharose beads (anti-mouse suspension $\mathrm{nr} 7$; KabiPharmacia AB, Uppsala, Sweden). The solution was stored at $4^{\circ} \mathrm{C}$ prior to use.

\section{Biological samples}

Plasma samples from 5 female llamas and 5 alpacas were kindly provided by Dr. J. Sumar (Instituto Veterinario de Investigaciones Tropicales y de Altura, Universidad Nacional Mayor de San Marcos, Lima, Peru). The animals were sampled immediately after mating and 4 days later.

Two adult male llamas were injected with GnRH (Receptal, Hoecht, $0.2 \mu \mathrm{g} \mathrm{kg}^{-1}$ B.W.) in order to induce pituitary $\mathrm{LH}$ release. Blood samples were collected immediately before the GnRH injection and every $15 \mathrm{~min}$ thereafter until 240 min post injection.

Two female llamas were injected intravenously with GnRH (Receptal, Hoecht, $0.2 \mu \mathrm{g}$
$\mathrm{Kg}^{-1}$ B.W.), and blood samples were collected every $15 \mathrm{~min}$ from immediately before injection until $240 \mathrm{~min}$ after injection. The same schedule was followed when the animals were 5,7 and 18 months old.

All blood samples were collected into heparinized tubes. Plasma was separated by centrifugation and stored at $-20^{\circ} \mathrm{C}$ until analyzed.

The amount of $\mathrm{LH}$ released after GnRH injection was estimated by calculating the areas under the release curve according to the formula:

LH response $=\Sigma\left(\left(\mathrm{LH}_{\mathrm{i}}+\mathrm{LH}_{\mathrm{i}}+15\right) / 2\right) \times 15 \mathrm{~min}$, where $\mathrm{i}=0,15,30,45 \ldots 240 \mathrm{~min}$.

\section{Initial $L H$ radioimmunoassay procedure}

The initial procedure was, in brief, as follows: $100 \mu \mathrm{L}$ of sample or standard was dispensed into polypropylene tubes, followed by $100 \mu \mathrm{L}$ of tracer and $100 \mu \mathrm{L}$ (containing $1 \mathrm{ng}$ ) of monoclonal antibody, except those used for total count and nonspecific binding, where $100 \mu \mathrm{L}$ of buffer was added. After mixing, tubes were incubated overnight at $4^{\circ} \mathrm{C}$. The precipitating solution $(1 \mathrm{ml})$ was added, and the tubes were incubated for another $30 \mathrm{~min}$ at room temperature. Finally, they were centrifugated for $20 \mathrm{~min}$ at $4^{\circ} \mathrm{C}$. Supernatants were decanted using foam decanting racks, and the tubes were left inverted for 2 min on absorbent paper. Radioactivity was measured in a gamma counter for $1 \mathrm{~min}$. Concentrations of $\mathrm{LH}$ were calculated from the mean of duplicate determinations.

\section{Oestradiol-17 $\beta$ assay}

Oestradiol-17ß was determined using an RIA previously validated for use in bovine plasma (Sirois \& Fortune 1990), with the following modification: the standard curve was prepared with standards supplied with the radioimmunoassay kit (Oestradiol-17ß double antibody RIA, Diagnostic Products Corpora- 


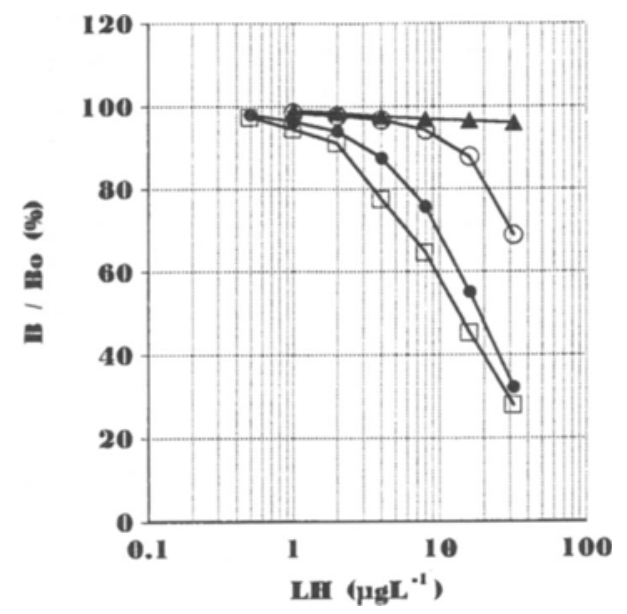

Figure 1: Standard curves obtained using 11 $\mathrm{ng} /$ tube of the MCA 146 antibody $(\boldsymbol{\Delta})$ and $1.0(\mathrm{O})$, $0.66(\bigcirc)$ and $0.33(\square) \mathrm{ng} /$ tube of the MAB 518 B7 antibody.

tion, Los Angeles, CA, USA). Serially diluted plasma from female llamas and alpacas containing high concentrations of oestradiol-17ß produced displacement curves parallel to the standard curve. The intra-assay coefficients of variation calculated from the precision profile of seven assays were $13.4 \%$ at $6 \mathrm{pmol} \mathrm{L}^{-1}$, $10.2 \%$ at $11 \mathrm{pmol} \mathrm{L}^{-1}$, and below $10 \%$ for concentrations up to $180 \mathrm{pmol} \mathrm{L}^{-1}$. The inter-assay coefficients of variation for three control samples were $25 \%$ (13 pmol L-1), 6\% (39 pmol L $\left.{ }^{-1}\right)$, and $10 \%\left(84 \mathrm{pmol} \mathrm{L}^{-1}\right)$. The lowest amount of oestradiol-17ß detectable (defined as the intercept of maximal binding - 2 SD) was 3 pmol L-1.

\section{Results}

\section{Evaluation of assay procedure}

Figure 1 shows standard curves obtained using the antibodies MAB 518B7 and MCA 146 and how the slope of the curve was affected by different concentrations of MAB

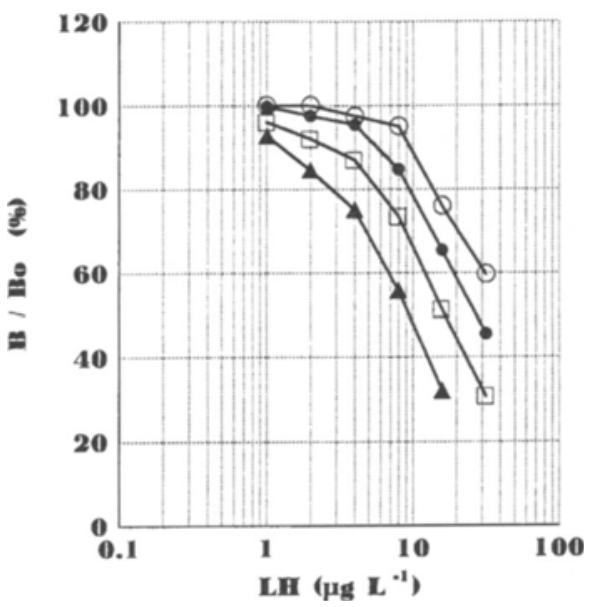

Figure 2: Calibration curves obtained when the antibody and the tracer were added simultaneously (O) as compared with those when $1 \mathrm{~h}(\mathbf{O}), 4 \mathrm{~h}$ at room temperature $(\square)$ and $24 \mathrm{~h}$ at $4^{\circ} \mathrm{C}(\boldsymbol{\Delta})$, preincubation preceded the addition of the tracer.

518B7. The MCA 146 antibody bound $20 \%$ of the human tracer at a concentration of 11 ng/tube. The antibody showed a stronger affinity for the hLH than for the eLH, resulting in poor displacement of the tracer. The MAB $518 B 7$ antibody bound $20 \%, 29 \%$ and $43 \%$ of the human tracer when used at concentrations of $0.33,0.66$ and $1.0 \mathrm{ng} /$ tube, respectively. When $0.33 \mathrm{ng} /$ tube was used, the amount of eLH needed to cause $50 \%$ inhibition was 15 $\mu \mathrm{g} \mathrm{L}^{-1}$ (S.D.= 0.7). In all cases, standards and antibody were preincubated for $1 \mathrm{~h}$ before adding tracer. The tubes were then incubated overnight at $4^{\circ} \mathrm{C}$. Further validation and clinical evaluation of the assay were performed using the MAB 518B7 antibody.

It is well known that one method of making an assay more sensitive is to add reagents sequentially, for example to incubate the unlabelled hormone with the antiserum and add the tracer later. Figure 2 shows the calibration 


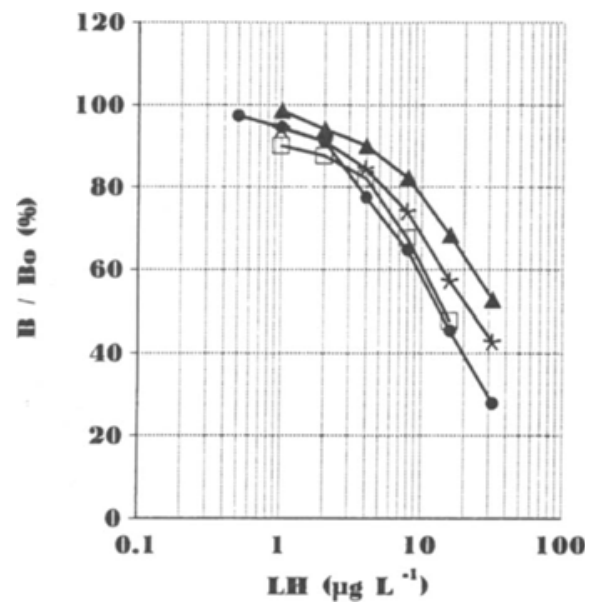

Figure 3: Calibration curves obtained when equine standard and human tracer were incubated with the MAB 518B7 antibody for $2 \mathrm{~h}$ at $37^{\circ} \mathrm{C}(\boldsymbol{\Delta})$, overnight at room temperature $(*)$, overnight at $4^{\circ} \mathrm{C}(\bigcirc)$ and $48 \mathrm{~h}$ at $4^{\circ} \mathrm{C}(\square)$.

curves obtained when the antibody and tracer were added simultaneously as compared with those obtained when $1 \mathrm{~h}, 4 \mathrm{~h}$ (at room temperature) or $24 \mathrm{~h}\left(\right.$ at $\left.4^{\circ} \mathrm{C}\right)$ of pre-incubation preceded addition of the tracer. All tubes were incubated for $24 \mathrm{~h}$ at $4^{\circ} \mathrm{C}$ after adding the tracer. The figure illustrates how the sensitivity of the assay was improved by extending the incubation periods of antibody and unlabelled hormone. Different incubation-period protocols were also tested. Figure 3 shows the calibration curves obtained when equine standard and human tracer were incubated with the MAB 518B7 antibody for $2 \mathrm{~h}$ at $37^{\circ} \mathrm{C}$, overnight at room temperature, overnight at $4^{\circ} \mathrm{C}$, and for $48 \mathrm{~h}$ at $4^{\circ} \mathrm{C}$. In all cases, tubes were preincubated for $1 \mathrm{~h}$ at room temperature before adding the tracer. As can be seen from the figure, prolonged incubation increased the steepness of the standard curves. However, the binding kinetics resulting from incu-

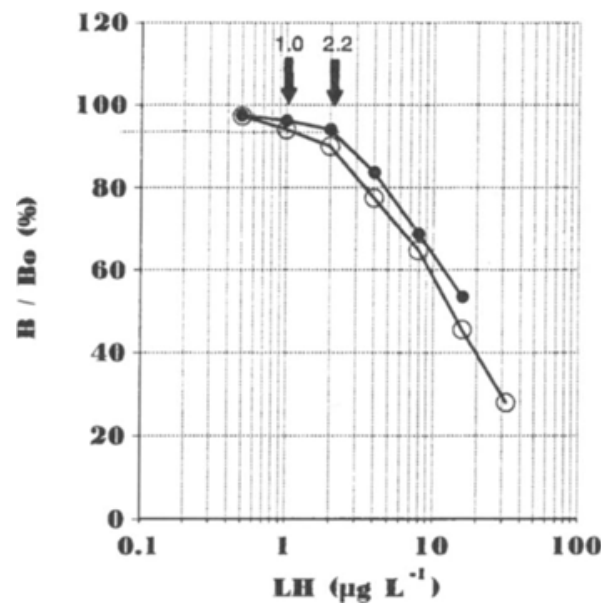

Figure 4: Difference in LH concentrations measured in the same sample when calculated against standard curves where standards were diluted in 100 $\mu \mathrm{L}$ buffer (O) or in $50 \mu \mathrm{L}$ human $\mathrm{LH}$ free serum and $50 \mu \mathrm{L}$ buffer $(\mathrm{O})$.

bation at $4^{\circ} \mathrm{C}$ overnight was similar to that resulting from $48 \mathrm{~h}$ of incubation.

Figure 4 illustrates the difference in the $\mathrm{LH}$ concentration measured in the same sample when calculated against standard curves where standards were diluted in human $\mathrm{LH}$ free serum $(50 \mu \mathrm{L}$ serum and $50 \mu \mathrm{L}$ assay buffer) and buffer $(100 \mu \mathrm{L})$. When standards were diluted in assay buffer and LH concentrations from plasma samples of llamas and alpacas were calculated, the measured concentrations were higher than expected. In samples predicted to have low concentrations of LH, they never decreased below $2-2.5 \mu \mathrm{g}$ $\mathrm{L}^{-1}$. When human serum was included in the standard curve, the corresponding values were 2 - 3 fold lower.

Based on the results obtained, the following protocol was adopted for the clinical validation of the assay: Assay buffer $(100 \mu \mathrm{L})$ was dispensed to all tubes. Standards $(50 \mu \mathrm{L}+50$ 


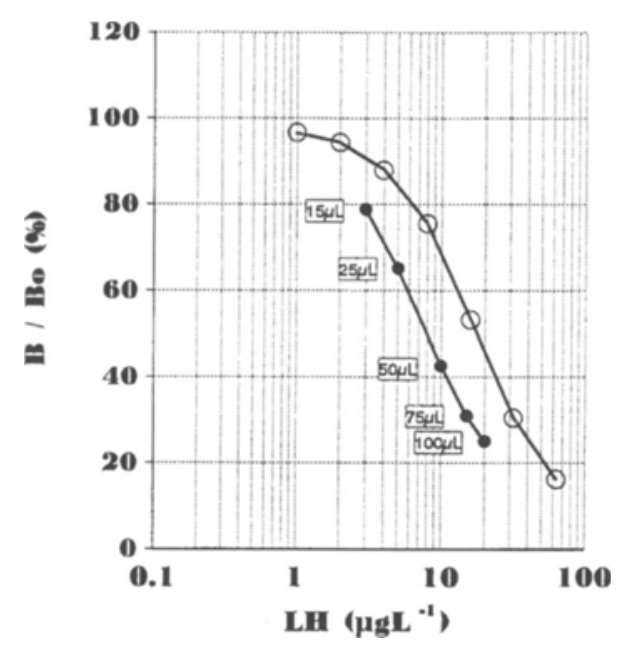

Figure 5: Standard curve $(\bigcirc)$ and parallel displacement curve $(\bullet)$ produced by serial dilutions from $100 \mu \mathrm{L}$ to $15 \mu \mathrm{L}$ of alpaca plasma containing high LH concentrations.

$\mu \mathrm{L}$ human $\mathrm{LH}$ free serum $)$ and samples $(50 \mu \mathrm{L}$ $+50 \mu \mathrm{L}$ assay buffer) were dispensed in duplicate into polypropylene tubes. The monoclonal antibody $\left(100 \mu \mathrm{L} ; 0.3 \mathrm{ng} \mathrm{L}^{-1}\right)$ was added to all tubes, except those used for total counts and for nonspecific binding, where $50 \mu$ of $\mathrm{hLH}$ free serum $+150 \mu \mathrm{l}$ assay buffer were added. After vortexing, standards and samples were pre-incubated for $60 \mathrm{~min}$ at room temperature, whereupon the LH tracer (100 $\mu \mathrm{l} ; 25.000 \mathrm{cpm}$ ) was added. The contents of the tubes were vortexed and incubated overnight at $4^{\circ} \mathrm{C}$. The precipitating solution $(1 \mathrm{ml})$ was added, and the tubes were incubated for another $30 \mathrm{~min}$ at room temperature followed by centrifugation for $20 \mathrm{~min}$ at $4^{\circ} \mathrm{C}$. Supernatants were decanted using foam decanting racks, and the tubes were left inverted for 2 min on absorbent paper. Radioactivity was measured in a gamma counter for $1 \mathrm{~min}$.

Figure 5 shows the standard curve and the parallel displacement curve produced by serial dilutions, from $100 \mu \mathrm{L}$ to $15 \mu \mathrm{L}$, of alpaca plasma containing high $\mathrm{LH}$ concentrations. A similar displacement curve was obtained when llama plasma was serially diluted.

The assay sensitivity (defined as the intercept of maximal binding - 2SD) was $0.8 \mu \mathrm{g} \mathrm{L}^{-1}$. The intra-assay coefficient of variation was $37 \%$ at $1 \mu \mathrm{g} \mathrm{L}^{-1}$, declined to $15 \%$ at $4 \mu \mathrm{g} \mathrm{L}^{-1}$ and was below $6 \%$ for concentrations up to $32 \mu \mathrm{g} \mathrm{L}^{-1}$. The inter-assay coefficients of variation for three control samples in five assays were $20 \%$ $\left(2.8 \mu \mathrm{g} \mathrm{L}^{-1}\right), 16 \%\left(7.1 \mu \mathrm{g} \mathrm{L}^{-1}\right)$, and $9.8 \%(19.0$ $\left.\mu \mathrm{g} \mathrm{L}^{-1}\right)$.

\section{Clinical validation}

In the samples obtained on the day of mating, LH was high in both llamas $\left(3.0 \pm 0.9 \mu \mathrm{g} \mathrm{L}^{-1}\right)$ and alpacas $\left(2.9 \pm 0.3 \mu \mathrm{g} \mathrm{L}^{-1}\right)$. By day 4 , concentrations had declined to the detection limit of the assay.

Figure $6 \mathrm{a}$ depicts the $\mathrm{LH}$ response to a single injection of GnRH in female llamas at different ages. Peak values were obtained approximately $120 \mathrm{~min}$ after injection and had declined to below the detection limit of the assay by $240 \mathrm{~min}$ after injection. Oestradiol-17ß concentrations ranged from 5 to $41 \mathrm{pmol} \mathrm{L}^{-1}$ in samples taken at the time of GnRH injection. The total amount of $\mathrm{LH}$ secreted after GnRH injection (estimated as the area under the curve) was 316-589, 576-696 and 459-1503 $\mu \mathrm{g}$ $\mathrm{L}^{-1} 240 \mathrm{~min}^{-1}$ at 5, 7 and 18 months of age, respectively. Fig. $6 \mathrm{~b}$ shows the increase in $\mathrm{LH}$ concentrations in peripheral circulation after GnRH challenge in two adult male llamas.

\section{Further assay validation}

One limitation of the assay was the relatively high detection limit $\left(0.8 \mu \mathrm{g} \mathrm{L}^{-1}\right)$. Therefore the following modifications were introduced into the assay protocol in an attempt to increase sensitivity: (1) all tubes were preincubated for 

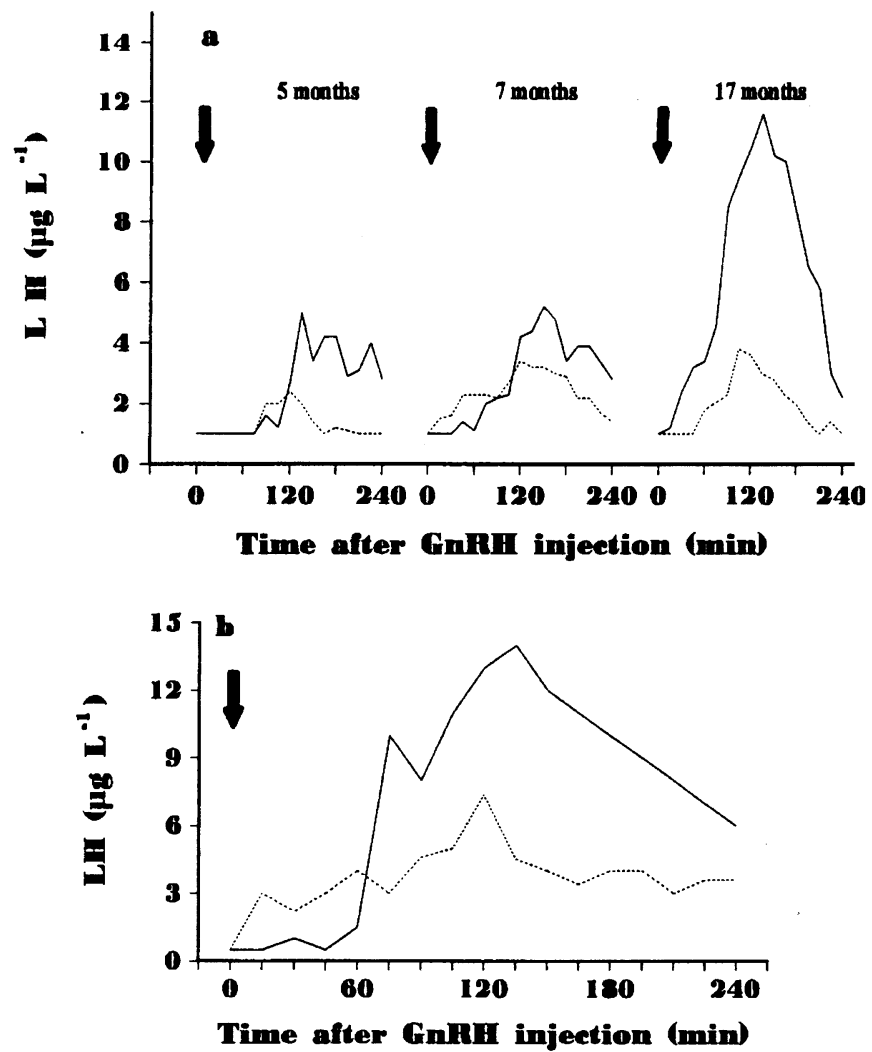

Figure 6: $\mathrm{LH}$ response to a single injection of GnRH ) in two female llamas at 5, 7 and 18 months of age (a) and in two adult males (b).

$4 \mathrm{~h}$ at room temperature before adding the tracer; (2) the sample volume was increased from $50 \mu \mathrm{L}$ to $100 \mu \mathrm{L}$ (in the standard curve the increased volume was compensated for by human LH free serum), and (3) the antibody concentration was increased to $0.6 \mathrm{ng} /$ tube. With this protocol the binding of the tracer in the zero standard was $25 \%$, and the assay sensitivity (defined as the intercept of maximal binding - 2SD) was $0.5 \mu \mathrm{g} \mathrm{L}^{-1}$. The intra-assay coefficients of variation were $18 \%$ at $1 \mu \mathrm{g} \mathrm{L}^{-1}$, to $8 \%$ at $4 \mu \mathrm{g} \mathrm{L}^{-1}$ and below $5 \%$ for concentra- tions up to $32 \mu \mathrm{g} \mathrm{L}^{-1}$. The inter-assay coefficients of variation for 3 control samples in 2 assays were $7 \%\left(4.4 \mu \mathrm{g} \mathrm{L} \mathrm{L}^{-1}\right), 1 \%(9.4 \mu \mathrm{g}$ $\left.\mathrm{L}^{-1}\right)$ and $2 \%\left(19.4 \mu \mathrm{g} \mathrm{L}^{-1}\right)$. Serially diluted llama and alpaca plasma samples produced displacement curves parallel to the standard curve.

\section{Discussion}

The competitive type of radioimmunoassay used in this study requires the availability of highly purified LH in amounts sufficient for 
labelling with iodine and for use as standards. For hLH and LH from the common domestic species this is generally not a problem. Many of the pituitary hormones can be obtained from research institutions or are available from commercial suppliers. For less investigated species, however, the supply of pituitary hormones is more restricted. In this study we circumvented this problem by utilizing an antibody specific for $\mathrm{LH}$, but with low species specificity, labelled hLH as tracer and $\mathrm{eLH}$ as the unlabelled standard to detect lamLH. One advantage of using radiolabelled $\mathrm{hLH}$ is that the hormone exists on the market either as bulk isotopes or as part of a kit. One can therefore avoid the iodination procedure with its potential health hazards.

The hLH used as tracer together with the MAB 518B7 antibody seem to function as a general assay procedure for measuring $\mathrm{LH}$ in several species (Forsberg et al. 1993). This is contradictory to the report by Matteri et al. (1987). They observed low cross-reactivity between hLH and the MAB 518B7. The diverging results could be due to the use of different hLH preparations.

When the eLH standards were diluted in assay buffer, unacceptably high concentrations of lamLH were observed, especially in samples predicted to have low concentrations. This problem was overcome by incorporating $\mathrm{hLH}$ free serum in the standard curve, thereby using the same serum volumes in standards and unknowns. The fact that measured concentrations of lamLH differed depending on whether or not serum was used suggests that matrix effects occurred, which may have been amplified by differences between the affinity of the antibody for lamLH and its affinity for eLH. We are currently evaluating the possibility of replacing LH standards with llama and alpaca serum where concentrations of $\mathrm{LH}$ in the camelid samples have been estimated against the equine reference.

Acceptable sensitivity and variation at low concentrations as well as low non-specific binding were obtained for sample volumes up to $100 \mu \mathrm{l}$. The sequential saturation of the antibody with unlabelled and labelled LH improved the sensitivity of the assay. A sample volume of $50 \mu \mathrm{l}$ and a preincubation period of $1 \mathrm{~h}$ were adequate for measuring high $\mathrm{LH}$ concentrations and detecting the preovulatory LH peak in llamas and alpacas, but sensitivity was not high enough to allow low baseline concentrations to be measured. To measure low concentrations of lamLH we recommend using the higher sample volume (100 $\mu \mathrm{l})$ and extending the preincubation period of antibody and unlabelled hormone to $4 \mathrm{~h}$.

There was good correspondence between the results of this study and those of a previous report, indicating that precopulatory $\mathrm{LH}$ concentrations in llamas are approximately $0.7 \mu \mathrm{g}$ $\mathrm{L}^{-1}$, with peak values $2 \mathrm{~h}$ after copulation ranging between 3 and $8 \mu \mathrm{g} \mathrm{L}^{-1}$ (Bravo et al. 1990). Furthermore, the recorded maximum concentrations and time course of the LH secretion after GnRH injection in female llamas and alpacas correlate well with the corresponding findings from an earlier study (Bravo et al. 1992). To our knowledge, this is the first report showing the $\mathrm{LH}$ response to GnRH challenge in male llamas. Taken together, the results confirm the clinical usefulness of the assay for monitoring LH secretory patterns in the two South American camelids. Bravo et al. (1991) suggested that the amount of $\mathrm{LH}$ released after copulation varies depending on follicular size and related to oestradiol-17ß concentrations. We did not observe any correlation between oestradiol concentrations in peripheral circulation and the amount of $\mathrm{LH}$ released after $\mathrm{GnRH}$ stimulation. Differences in the age of the stud- 
ied animals and different $\mathrm{LH}$ releasing stimulus may explain the divergent observations. Finally, let us return to the question raised in the introduction. Is the method described in this paper a valid assay for lamLH? The different test protocols provided considerable information about the properties and limitations of the assay. However, we consider the assay system validated from diagnostic and clinical points of view. Relative concentrations of $\mathrm{LH}$ can be measured in the peripheral circulation of llamas and alpacas. This is the main information required when studying $\mathrm{LH}$ secretory patterns, rather than absolute concentrations of the hormone.

\section{Acknowledgements}

We thank the Swedish Agency for Research in Developing Countries (SAREC), the Swedish International Programme on Animal Reproduction (SIPAR), the Swedish International Development Agency (SIDA) and the Department of Physiopathology, Faculty of Veterinary Sciences, UNCPBA, Tandil, Argentina, for financial support.

\section{References}

Bravo PW, Fowler ME, Stabenfeldt GH, Lasley BL: Endocrine responses in the llama to copulation. Theriogenology, 1990, 33, 891-899.

Bravo PW, Stabenfeldt GH, Fowler ME, Lasley BL: Pituitary response to repeated copulation and/or Gonadotropin-Releasing hormone administration in llamas and alpacas. Biol. Reprod., 1992, 47, 884-888.

Bravo PW, Stabenfeldt GH, Lasley BL, Fowler ME: The effect of ovarian follicle size on pituitary and ovarian responses to copulation in domesticated South American camelids. Biol. Reprod., 1991, 45, 553-559.

Forsberg M, Tagle R, Madej A, Molina JR, Carlsson $M A$ : Radioimmunoassay of bovine, ovine and porcine luteinizing hormone with a monoclonal antibody and a human tracer. Acta vet. scand., 1993, 34, 255-262.

Kofler R, Kalchschmid E, Berger P, Wick G: Production and characterization of monoclonal antibodies against bovine Luteinizing Hormone. Immunobiology, 1981, 160, 196-207.

Matteri RL, Roser JF, Baldwin DM, Lipovetsky V, Papkoff $H$ : Characterization of a monoclonal antibody which detects luteinizing hormone from diverse mammalian species. Domest. An. Endocrinol., 1987, 4, 157-165.

Novoa C: Reproduction in camelidae: a review. J. Reprod. Fert., 1970, 22, 3-20.

Niswender GD, Reichert LE, Midgley AR, Nalbandov $A V$ : Radioimmunoassay for ovine and bovine luteinizing hormone. Endocrinology, 1969, 84, 1166-1173.

Sirois J, Fortune JE: Lengthening the bovine estrous cycle with low levels of progesterone: a model for studing ovarian follicular dominance. Endocrinology, 1990, 127, 916-924.

\section{Sammanfattning}

Utvärdering av en radioimmunologisk metod (RIA) för analys av luteiniserande hormon (LH) hos lama och alpaca.

I analysen användes en monoklonal antikropp, specifik för LH, men med låg artspecificitet och joderat humant LH som markör samt equint LH som standard. Antikroppen band LH från lama, alpaca och häst likvärdigt. För att detektera LH utsöndringen i samband med ovulation krävdes att antikropp och standard/prov inkuberades i 1 timme innan den radioaktiva markören tillsattes. Analysens känslighet ökade om inkubationstiden utsträcktes till 4 timmar. Separation av antikroppsbundet och fritt LH utfördes med en andra antikropp bunden till Sepharose gel. Inomkörningsvariationen var lägre än $15 \%$ vid $4 \mu \mathrm{g} \mathrm{L}^{-1}$ och mellankörningsvariationen lägre än $20 \%$ vid $2.8 \mu \mathrm{g} \mathrm{L}^{-1}$. Metodens kliniska användbarhet verifierade genom analys av LH i blodprover tagna efter vid olika tidpunkter efter GnRH injektion hos lamor av båda könen. Dessutom kunde metoden detektera $\mathrm{LH}$ frisättningen efter parning hos både lama och alpaca.

(Received March 6, 1995; accepted May 24, 1995).

Reprints may be obtained from: Dr. M. Aba, Department of Physiopathology, Faculty of Veterinary Sciences, U.N.C.P.B.A., Campus Universitario, Paraje Arroyo Seco, Tandil, Buenos Aires, Argentina. 
